\title{
Crying with a Smile: An Oncologist's Emotional Moment
}

\author{
Venkata Pradeep Babu Koyyala \\ ${ }^{1}$ Medical Oncology, Homi Bhaba Cancer Hospital and Research \\ Center, Visakhapatnam, Andhra Pradesh, India
}

Ind J Med Paediatr Oncol 2021;42:99.

I practice medical oncology in my small chamber. Spending most of my current life in that small place, for about 10 hours a day quietly, I see most horrendous accidents that can happen in the lives of many people and their families. The seriousness of discussions undermines anything such as what is a nuclear threat for a nation. I see the strongest men reducing to tears during those discussions and a poor person who strives to eat three times a day getting ready to arrange for the treatment of dear one's costing his entire life's earnings. I see the ultimate sacrifices and unbearable pain, all with the same expression, without shedding a tear. My heart cries for them, but I manage to smile. My tears will increase their pain, defeat their purpose of traveling so far with a hope. However, not always can we hide our tears!

I live away from my family for my job, as my wife takes care of our 6-month-old daughter. My most favorite time of the day is late evenings when I get to see her smile and listen to the cooing sounds, she makes. Every time I see her, I realize that from the moment a daughter is born, the personality of a father improves, always for the better. As usual, my wife called me and after a minute, she stared in her mobile screen and asked "Wait, do you have tears in your eyes?" I said, "No. I am not." But, hiding emotional feelings from the closest people is almost impossible. That's why they are called as family. I immediately hung up. She called me again. Asked me "Are you feeling alone? Did you see anyone suffering too much?" This time she got me. She gets me every time when I'm lying, so easily. Sharing the emotions is the only way out that can relieve us, and for anyone, anytime.

I narrated to her the reason for the involuntary tears, looking at my daughter. The reason is one of our incredibly young and energetic 21 -year-old patients who had come to the outpatient department for reevaluation after neoadjuvant chemotherapy for her locally advanced rectal cancer. Her enthusiasm is like a wind at the mountain cliff. We would
Address for correspondence Venkata Pradeep Babu Koyyala, MD, DNB, Medical Oncology, Homi Bhaba Cancer Hospital and Research Center, Visakhapatnam, 530046, Andhra Pradesh, India (e-mail: pradeepbabu.koyyala@gmail.com).

ask depressed patients to meet her and talk to her to make them feel better. She responded very well clinically, but her response radiologically is not enough to undergo a good and minimal surgery. The case was discussed in the tumor board and decided that she may need further chemotherapy and because of the location of the tumor, she might require permanent colostomy even with the best response. Her father came to our department to discuss the further plan. He said "Today my daughter wants to talk to you about the decision of the tumor board. She doesn't feel like coming here. She said she is not feeling good today," and he continued "Sir, is it true that my daughter requires permanent colostomy as the surgeon said?" I paused briefly. The pause continued. I rarely take such a long pause while explaining the management plan. After discussing, he left and before leaving, he said "Sir, as a doctor, please do whatever best you can do. And please don't disclose it to her so early that she might need a permanent bag," and he left.

At that moment, each thought in my mind weighed so heavily that brought my mood to the rock bottom in a split second. I think it happens with every medical oncologist. That heaviness dissolved into tears, when I saw the little smile on the face of my daughter. Giving such a difficult news for another father has weighed heavily on me. Hearing all the story, my wife looked at me with confused expressions, not knowing what to say. She said, "Don't worry, maybe you are too sensitive.... But tears are good sometimes." I replied silently "Probably, I am a Medical oncologist in the making, I need to master the art of 'Crying with a smile' while choosing the life over limb of a patient."

\section{Financial support and sponsorship}

Nil.

\section{Conflicts of interest}

There are no conflicts of interest.
DOI https://doi.org/ $10.1055 / \mathrm{s}-0041-1729436$ ISSN 0971-5851
(C) 2021. Indian Society of Medical and Paediatric Oncology This is an open access article published by Thieme under the terms of the Creative Commons Attribution-NonDerivative-NonCommercial-License, permitting copying and reproduction so long as the original work is given appropriate credit. Contents may not be used for commercial purposes, or adapted, remixed, transformed or built upon. (https://creativecommons.org/licenses/by-nc-nd/4.0/). Thieme Medical and Scientific Publishers Pvt. Ltd. A-12, 2nd Floor, Sector 2, Noida-201301 UP, India 